\title{
Potentially inappropriate medication use in a city of Southeast Brazil
}

\author{
Mauro Cunha Xavier Pinto1, Felipe Ferré2, Marcos Luciano Pimenta Pinheiro ${ }^{3, *}$
}

${ }^{1}$ Department of Pharmacy, College of Biological Sciences and Health, Federal University of Jequitinhonha and Mucuri Valleys; ${ }^{2}$ Department of Biochemistry and Immunology, Biological Sciences Institute, Federal University of Minas Gerais, ${ }^{3}$ Department of Basic Sciences, College of Biological Sciences and Health, Federal University of Jequitinhonha and Mucuri Valleys

\begin{abstract}
Potentially inappropriate medication use by the Diamantina (Minas Gerais State) population was investigated by analyzing medicine consumption, self-medication, polypharmacy and drug interactions of medicines prescribed among those interviewed. Level of knowledge about rational drug use and its relationship to socio-economic variables was also evaluated using a semi-structured questionnaire. This survey was based on stratified sampling of 423 individuals selected randomly. The prevalence of prescription drug consumption was $42.32 \%(\mathrm{n}=179)$ and cardiovascular drugs were the most prescribed. Drug interactions were found in $45.81 \%(\mathrm{n}=82)$ of prescriptions and $92.68 \%(\mathrm{n}=76)$ of these interactions were moderate, with co-administration of cardiovascular drugs occurring in more than half of the cases. The inappropriate use of medication, according to Beers criteria, occurred in $44.73 \%$ of prescriptions to the elderly. The prevalence of self-medication was $63.34 \%(n=268)$ while $21.99 \%(n=91)$ of individuals administered medications to their children without formal prescriptions, where this practice was associated to analgesic/antipyretic consumption. The population showed a high prevalence of inappropriate use of drugs across all strata of society, representing an issue requiring effective actions to promote rational use of medicines.
\end{abstract}

Uniterms: Medicines/rational use. Medicines/inappropriate use. Self-medication. Pharmacoepidemiology.

O consumo inapropriado de medicamentos pela população de Diamantina-MG foi investigado através da análise do consumo de medicamentos, automedicação, polifarmácia e interações medicamentosas prescritas aos entrevistados. Também foi avaliado o nível de conhecimento sobre uso racional de medicamentos e sua relação com variáveis sócio-econômicas através de um questionário semi-estruturado. Este estudo transversal foi baseado em amostragem estratificada e contou com a participação de 423 indivíduos selecionados aleatoriamente. A prevalência do consumo de medicamentos prescritos foi de $42,32 \%$ ( $n=179)$, sendo os medicamentos cardiovasculares os mais prescritos. Entre as prescrições foram encontradas 45,81\% $(n=82)$ de interações medicamentosas, sendo 92,68\% $(n=76)$ destas interações moderadas e a co-administração de medicamentos cardiovasculares presente em mais da metade dos casos. O uso inadequado de medicamentos, segundo os critérios de Beers, esteve presente em 44,73\% das prescrições de idosos. Com relação à automedicação, 63,34\% $(n=268)$ dos entrevistados admitem fazer uso de medicamento sem prescrição e 21,99\% (n=91) administram medicamentos aos filhos sem prescrição profissional, sendo os analgésicos e antitérmicos os mais comumente administrados em ambas as situações. A população avaliada apresentou alta prevalência de uso inadequado de medicamentos observados em todas as camadas da sociedade, sendo necessário estabelecer medidas eficazes para promoção do uso racional de medicamentos.

Unitermos: Medicamentos/uso racional. Medicamentos/consumo inapropriado. Automedicação. Farmacoepidemiologia.

\footnotetext{
*Correspondence: M. L. P. Pinheiro. Departamento de Ciências Básicas, Faculdade de Ciências Biológicas e da Saúde, Universidade Federal dos Vales do Jequitinhona e Mucuri. Rua da Glória, 187 - Centro - 39100-000 - Diamantina MG, Brazil. E-mail: marcospimenta@ufvjm.edu.br
} 


\section{INTRODUCTION}

Medicines are an important therapeutic tool used for treating diseases, accounting for a significant improvement in health status of the population when used in a rational manner (Aquino, 2008; Arrais et al., 1997; Vilarino et al., 1998). The rational use of medicines is characterized by patients receiving appropriate medications for their clinical needs, at individually adjusted doses and dosage regimens for a set period of time at lowest cost (Aquino, 2008). However, in Brazil the inappropriate use of medication is common in the context of polypharmacy, self-medication and drug interactions, and can result in the occurrence of iatrogenic diseases or poisoning (Loyola Filho et al., 2002; Hohl et al., 2001).

Polypharmacy, defined as the use of two or more drugs at the same time, occurs mainly in elderly patients with comorbidities, but may also take place due to lack of coordination between prescribers and self-medication concomitantly with the prescribed treatment (Loyola Filho et al., 2008; Rozenfeld et al., 2008). The most common problem found in polypharmacy prescriptions is drug interactions, responsible for some adverse drug reactions in patients (Hohl et al., 2001). Subjects in use of three or more drug therapies commonly complain of sleep disorders, dizziness, vertigo, nasal congestion, dry mouth, abnormalities in motor coordination, abdominal discomfort, constipation, reduced libido and edema (Almeida et al., 1999). For elderly, the estimated drug interaction risk is $13 \%$ for people using two medications and $58 \%$ among those taking five drugs (Secoli, 2010). In Brazil, there are few population-based studies on drug interactions while the technology to detect these interactions is generally unavailable to physicians, nurses and pharmacists, rendering the monitoring of medication-related problems in patients a challenging task.

Another problem related to drug consumption is self-medication, a form of self-administered health care where the individual takes medication on their own initiative, described as an alternative in individuals faced with limited access to health services occurring in all ages groups, is a reflection of the needs and habits of the population (Arrais et al., 1997; Loyola Filho et al., 2002; Sá et al., 2007). The indiscriminate use of drugs can aggravate or mask pathological conditions and cause adverse reactions, constituting an underestimated risk for individuals resorting to self-care instead of professional health care (Loyola Filho et al., 2008; Arrais et al., 1997).

In Brazil, data from the National Poisoning Information System - SINITOX points to medicines as key contributors to occurrences of poisoning, with more than
25,000 poisoning cases by drugs registered in 2009 , resulting in 71 deaths (Brasil, 2009). Furthermore, half of these cases occurred in people younger than 19 years of age, an alarming statistic, especially given the high incidence of children and adolescents receiving medication administered by the family without proper prescription (Brasil, 2007; Pereira et al., 2007).

Understand the pharmacoepidemiological profile and determining factors of medication consumption is an important tool toward promoting the rational use of medicines in many communities. Based on this premise, the objective of this study was to investigate the inappropriate use of medication in Diamantina - Minas Gerais State, a city in southeastern Brazil, by evaluating the consumption, self-medication, polypharmacy and drug interactions of members of the population.

\section{METHODS}

A population-based cross-sectional study was conducted in the city of Diamantina, located in Southern Brazil, Minas Gerais State, that has an urban population of around 29565 inhabitants (Brasil, 2001). Stratified sampling was used whereby the city was divided into 26 sectors with each household considered a stratum, based on data from the National Census (Brasil, 2001). Households were randomly selected for application of a semi-structured survey. The goal of applying the questionnaire was to obtain information from the interviewees on prescription drugs, self-medication, types of drugs consumed, level of knowledge about rational drug use and also to obtain a demographic and socio-economic profile of the research subjects.

To establish sample size, a model of proportional stratified sampling was adopted, with sample deviation of $5.0 \%$ and confidence level of $95.0 \%$. The probability of occurrence of the event "medication consumption" was $50 \%$ according to Carvalho et al, 2005. A total of 423 questionnaires were collected and evaluated, with inclusion of those individuals aged over 18 currently residing at the selected households. The volunteers were informed about the purpose and conditions of the study, and agreed to participate by signing the written Term of Consent, in accordance with the rules governing health research regulated by resolution 196/96 of 10/10/1996 by the National Health Council/MS. This study was approved by the Research Ethics Committee of the University of the Valleys of Jequitinhonha and Mucuri (CEP Registration / UFVJM No. 082/07) and had no conflict of interest.

The database was subjected to a pretreatment system for input into a MySQL database (version 5.1.37) employ- 
ing SQL queries for patients, age, gender, prescription drugs, dose and dosage regimen. Drug names were classified using the Brazilian Nonproprietary Name - DCB, and active principles classified according to the Anatomical Therapeutic Chemical Classification of the World Health Organization -ATC/WHO (WHO, 2010). The prescription drugs were evaluated according to the Brazilian National List of Essential Medicines - RENAME and using indicators proposed by the World Health Organization-WHO (WHO, 2010; Brasil, 2008). The therapy, dose and dosage regimen were evaluated using Beers criteria for potentially inappropriate medication use in older adults (Fick et al., 2003). Drug interactions were assessed two by two and classified by severity (major, moderate or minor).

The R project software (version 2.11.1) was used to evaluate statistical data. The normal distribution was tested with the Shapiro-Wilk normality test (Royston, 1982). Non-parametric data was analyzed with the MannWhitney test. Data were expressed as mean \pm standard deviation. Groups were compared with Pearson's Chi- squared test, and when the matrix was $2 \times 2$, Yates' continuity correction was carried out.

\section{RESULTS}

Among the individuals interviewed $(n=423)$, a prevalence of $42.32 \%$ of prescription medicine use was found and associated with gender, age, marital status and educational level (Pearson's Chi-squared test, $\mathrm{p}<0.05$ ). The prevalence of prescription medicines use was higher among women than men and, as expected, medicine consumption was higher in the elderly (older than 60 years old) than the young. Widowers and divorcees had higher consumption of medication and incomplete schooling. No differences between prescription medicine use and family income were identified in this work (Pearson's Chi-squared test, $\mathrm{p}>0.05)$. The results are shown in Table I.

A total of 378 medications were prescribed, $65.08 \%$ of which were listed in the National List of Essential Medicines -RENAME, giving an average of $1.54 \pm 2.06$ medi-

TABLE I - Absolute frequency and prevalence of prescription medicine use by respondents according to demographic and socioeconomic factors $(\mathrm{n}=179)$

\begin{tabular}{|c|c|c|c|c|}
\hline Independent variables & Yes & No & Prevalence (\%) & P value* \\
\hline \multicolumn{5}{|l|}{ Gender ** } \\
\hline Female & 146 & 160 & 47.71 & \multirow[t]{2}{*}{$\mathrm{p}<0.001$} \\
\hline Male & 33 & 84 & 28.21 & \\
\hline \multicolumn{5}{|l|}{ Age ** } \\
\hline 18 to 29 & 17 & 92 & 15.60 & \multirow[t]{5}{*}{$\mathrm{p}<0.001$} \\
\hline 30 to 44 & 28 & 83 & 25.23 & \\
\hline 45 to 59 & 58 & 54 & 51.79 & \\
\hline 60 to 74 & 58 & 12 & 82.86 & \\
\hline$>75$ & 18 & 03 & 85.71 & \\
\hline \multicolumn{5}{|l|}{ Marital status ** } \\
\hline Single & 33 & 112 & 22.76 & \multirow[t]{3}{*}{$\mathrm{p}<0.001$} \\
\hline Married & 95 & 100 & 48.72 & \\
\hline Widower/Divorced & 51 & 32 & 61.45 & \\
\hline \multicolumn{5}{|l|}{ Educational Level ** } \\
\hline Illiterate & 02 & 00 & 100.00 & \multirow[t]{7}{*}{$\mathrm{p}<0.001$} \\
\hline Incomplete elementary school & 89 & 63 & 58.55 & \\
\hline Elementary school & 24 & 26 & 48.00 & \\
\hline Incomplete high school & 09 & 34 & 20.93 & \\
\hline High School & 31 & 75 & 29.25 & \\
\hline Incomplete university & 03 & 22 & 12.00 & \\
\hline University & 21 & 24 & 46.67 & \\
\hline \multicolumn{5}{|l|}{ Family Income } \\
\hline$<03$ Wages & 116 & 169 & 40.70 & \multirow[t]{4}{*}{$\mathrm{p}>0.05$} \\
\hline 03 to 05 Wages & 36 & 46 & 43.90 & \\
\hline 05 to 10 Wages & 22 & 22 & 50.00 & \\
\hline$>10$ Wages & 05 & 07 & 41.67 & \\
\hline
\end{tabular}

* Pearson's Chi-squared test. ** Significant difference between observed and expected frequencies for $\mathrm{p}<0.05$. 
cations per patient. The group predominantly prescribed was cardiovascular drugs, representing $51.59 \%$ of all prescriptions, followed by nervous system drugs accounting for $21.16 \%$ with alimentary tract and metabolism drugs constituting $9.52 \%$ of prescriptions. Antihypertensive drugs such as hydrochlorothiazide and captopril were the most prescribed by physicians. The drugs prescribed are given in Table II.

TABLE II - Absolute and relative frequencies of drug classes by prescriptions

\begin{tabular}{lcc}
\hline Chemical substance* & $\begin{array}{c}\text { Absolute } \\
\text { Frequency }\end{array}$ & $\begin{array}{c}\text { Relative } \\
\text { Frequency (\%) }\end{array}$ \\
\hline Hydrochlorothiazide & 35 & 19.55 \\
Captopril & 26 & 14.53 \\
Propranolol & 20 & 11.17 \\
Enalapril & 12 & 6.70 \\
Nifedipine & 12 & 6.70 \\
Simvastatin & 12 & 6.70 \\
Acetylsalicylic acid & 11 & 6.15 \\
Fluoxetine & 11 & 6.15 \\
Levonorgestrel and & 11 & 6.15 \\
Ethinylestradiol & & \\
Furosemide & 10 & 5.59 \\
Levothyroxine sodium & 10 & 5.59 \\
Atenolol & 09 & 5.03 \\
Chlorthalidone & 09 & 5.03 \\
Diazepam & 09 & 5.03 \\
Others & 09 & 5.03 \\
\hline
\end{tabular}

* Cut-off: $5 \%$

Drug interactions were detected in 82 prescriptions, the majority being moderate cases $(92.68 \%)(n=76)$. A total of 166 combinations were identified, the majority being interactions between cardiovascular system drugs (54.22\%), followed by cardiovascular drugs and nervous systems drugs $(32.53 \%)$ and interactions between nervous system drugs $(9.64 \%)$. The drug interactions are given in Table III.

Specific evaluation of the elderly population $(n=91)$ revealed a higher prevalence of prescription medication consumption of $83.52 \%(\mathrm{n}=76)$ and an elevated average number of medicines consumed of $2.79 \pm 1.89$. In this population, $53.95 \%$ consumed $2-4$ medications (minor polypharmacy) and $17.11 \%$ consumed more than 5 medications. Inappropriate medicine use according to the Beers criteria was identified in $30.26 \%(\mathrm{n}=23)$ of cases for women and $14.47 \%(n=11)$ of cases for men, a difference
TABLE III - Absolute and relative frequencies of drug interactions in prescriptions

\begin{tabular}{lcc}
\hline Chemical substance* & $\begin{array}{c}\text { Absolute } \\
\text { Frequency }\end{array}$ & $\begin{array}{c}\text { Relative } \\
\text { Frequency (\%) }\end{array}$ \\
\hline $\begin{array}{l}\text { Hydrochlorothiazide X } \\
\text { Captopril }\end{array}$ & 14 & 17.07 \\
$\begin{array}{l}\text { Hydrochlorothiazide X } \\
\text { Propranolol }\end{array}$ & 14 & 17.07 \\
$\begin{array}{l}\text { Hydrochlorothiazide X } \\
\text { Enalapril }\end{array}$ & 12 & 14.63 \\
Furosemide X Captopril & 10 & 12.20 \\
Furosemide X Propranolol & 10 & 12.20 \\
Digoxin X Captopril & 08 & 9.76 \\
Digoxin X Furosemide & 08 & 9.76 \\
Captopril X Diazepam & 06 & 7.32 \\
Diazepam X Fluoxetine & 04 & 4.88 \\
Digoxin X Spironolactone & 04 & 4.88 \\
Hydrochlorothiazide X & 04 & 4.88 \\
Amitriptyline & & \\
Hydrochlorothiazide X & 04 & 4.88 \\
Diazepam & & \\
Spironolactone X Captopril & 04 & 4.88 \\
\hline * Cut-off: $4 \%$ & &
\end{tabular}

which reached significance $(\mathrm{p}<0.05)$. The most inappropriate drug prescribed was digoxin, present in $27.27 \%$ of prescriptions. The inappropriate drugs according to Beers Criteria are shown in Table IV.

TABLE IV - Absolute and relative frequencies of inappropriate drug use according to Beers criteria by prescriptions

\begin{tabular}{lcc}
\hline Chemical substance* & $\begin{array}{c}\text { Absolute } \\
\text { Frequency }\end{array}$ & $\begin{array}{c}\text { Relative } \\
\text { Frequency (\%) }\end{array}$ \\
\hline Digoxin & 12 & 27.27 \\
Ferrous sulfate & 10 & 22.73 \\
Thioridazine & 06 & 13.64 \\
Nifedipine & 05 & 11.36 \\
Lorazepam & 05 & 11.36 \\
\hline
\end{tabular}

*Cut-off: $5 \%$

The prevalence of self-medication was $63.34 \%$ $(n=268)$ and was associated with gender and educational level (Pearson's Chi-squared test, $\mathrm{p}<0.05$ ). As observed in prescription medication use, self-medication was more prevalent in women (66.67\%) than men ( 54.70\%). Evaluating self-medication according to age group found that the elderly had a prevalence of $42.86 \%$, a lower rate 
TABLE V - Absolute frequency and prevalence of self-medication by respondents according to demographic and socio-economic factors $(n=268)$

\begin{tabular}{|c|c|c|c|c|}
\hline Independent variables & Yes & No & Prevalence $(\%)$ & p value* \\
\hline \multicolumn{5}{|l|}{ Gender ** } \\
\hline Female & 204 & 102 & 66.67 & \multirow[t]{2}{*}{$\mathrm{p}<0.05$} \\
\hline Male & 64 & 53 & 54.70 & \\
\hline \multicolumn{5}{|l|}{ Age } \\
\hline 18 to 29 & 74 & 35 & 67.89 & \multirow[t]{5}{*}{$\mathrm{p}>0.05$} \\
\hline 30 to 44 & 75 & 36 & 67.57 & \\
\hline 45 to 59 & 72 & 40 & 64.29 & \\
\hline 60 to 74 & 38 & 32 & 54.29 & \\
\hline$>75$ & 09 & 12 & 42.86 & \\
\hline \multicolumn{5}{|l|}{ Marital status } \\
\hline Single & 89 & 56 & 61.38 & \multirow[t]{3}{*}{$\mathrm{p}>0.05$} \\
\hline Married & 134 & 61 & 68.72 & \\
\hline Widower/Divorced & 45 & 38 & 54.22 & \\
\hline \multicolumn{5}{|l|}{ Educational Level ** } \\
\hline Illiterate & 01 & 01 & 50.00 & \multirow[t]{7}{*}{$\mathrm{P}<0.05$} \\
\hline Incomplete elementary school & 98 & 54 & 64.47 & \\
\hline Elementary school & 23 & 27 & 46.00 & \\
\hline Incomplete high school & 26 & 17 & 60.47 & \\
\hline High School & 73 & 33 & 68.87 & \\
\hline Incomplete University & 18 & 07 & 72.00 & \\
\hline University & 29 & 16 & 64.44 & \\
\hline \multicolumn{5}{|l|}{ Family Income } \\
\hline$<03$ Wages & 176 & 109 & 61.75 & \multirow[t]{4}{*}{$\mathrm{p}>0.05$} \\
\hline 03 to 05 Wages & 54 & 28 & 65.85 & \\
\hline 05 to 10 Wages & 30 & 14 & 68.18 & \\
\hline$>10$ Wages & 08 & 04 & 66.67 & \\
\hline
\end{tabular}

* Pearson's Chi-squared test. ** Significant difference between observed and expected frequencies for $\mathrm{p}<0.05$.

compared to that among the young of $67.89 \%$. No differences in self-medication was found for marital status or family income (Pearson's Chi-squared test, $\mathrm{p}>0.05$ ). The results are shown in Table $\mathrm{V}$.

In this study, 93 (21.99\%) respondents were found to administer medications to children without prescription from health professionals, and the prevalence of individuals who practiced self-medication was $82.80 \%$. According to medicine classes used for self-medication, there was no significant difference between children and adults, with the most used classes being analgesics/antipyretics ( $91.79 \%$ in adults and $88.87 \%$ in children), followed by anti-inflammatories $(31.72 \%$ in adults and $33.33 \%$ in children) and antibiotics (14.55\% in adults and $17.20 \%$ in children).

The last question addressed the relationship between individuals and medications. Among subjects who self-medicated, $70.52 \%$ reported being aware of the risks associated with self-medication, but only $21.27 \%$ reported that the sale of prescription drugs without a formal pre- scription had been denied while $8.58 \%$ reported having been negatively affected by the use of medication.

\section{DISCUSSION}

The prevalence of consumption of prescription drugs by the population of a city in the Southeast of Brazil was found to be slightly lower to levels in the South and Northeast of the country (Paniz et al., 2008). The prevalence of prescription medication consumption was higher among women than men. This result is consistent with the literature, a finding commonly attributed to greater concern for both own and family health by women compared to men. Moreover, numerous preventive public health programs are directed toward women (prenatal care, prevention of cervical and breast cancers), rendering them more prone to receiving professional prescriptions (Ribeiro et al., 2008). The prevalence of prescription drugs had a direct association with age of the interviewees, which may be explained by the increased incidence of chronic diseases at 
advanced ages and continuous use of medications (Flores, Benvegnú, 2008; Flores, Mengue, 2005).

Prescription rates for cardiovascular, endocrine and psychoactive drugs were higher than the national average, a fact which warrants special attention because their indiscriminate use can cause serious side effects and dependence (Carvalho et al., 2005). Most drug interactions found were considered moderate, with interactions between cardiovascular drugs showing the highest prevalence. Coadministration with antihypertensive agents, vasodilators and alpha-blockers are commonly prescribed by physicians, but may result in additive effects on blood pressure causing hypotension and hypovolemia (James et al. 1999). Thus, these drug combinations require frequent monitoring of blood pressure, diuresis, electrolytes and renal function.

Almost half of the population that consumed medications presented some degree of polypharmacy. The prevalence of medication use among the elderly in the study $(86.81 \%)$ was close to levels found in other Brazilian cities of Bambuí-Minas Gerais State and Rio de Janeiro - Rio de Janeiro State, whose prevalences were higher than $80 \%$. In terms of major polypharmacy (17.11\%) however, consumption for Diamantina was lower than these cities, with prevalences of $25.5 \%$ and $32.7 \%$, respectively (Rozenfeld et al., 2008; Loyola Filho et al., 2008).

Evaluating the elderly population, more than half of this group who took medications had an inappropriate drug in the prescription. Elderly patients commonly manifest physiological changes such as reduction in renal and hepatic functions, which may alter the pharmacokinetics and/or pharmacodynamics of drugs, causing more severe adverse or therapeutic effects (Hanratty et al., 2000). The most inappropriate medication prescribed, digoxin, is associated with a high risk of developing toxicity while diagnosing digoxin toxicity can be difficult in this patient group (Hanratty et al., 2000). Special care of these patients is necessary to avoid morbidly and mortally caused by medication use.

The prevalence of self-medication was higher than the rate in Santa Maria-Rio de Janeiro State (53.3\%), Bambuí-Minas Gerais State $(\sim 45 \%)$ and the national average ( $\sim 50 \%)$ (Arrais et al., 1997; Loyola Filho et al., 2002; Vilarino et al., 1998). Overall, women had a higher self-medication prevalence compared to men, as previously demonstrated for the consumption of prescription drugs, a finding consistent with other studies conducted throughout Brazil (Loyola Filho et al., 2002; Ribeiro et al., 2008; Vitor et al., 2008). Self-medication was strongly correlated to age group, with elderly persons having a high prevalence of prescription drugs and low prevalence of self-medication. This finding can be explained by the negative association between the presence of chronic diseases, visits to physicians and the practice of self-medication, a correlation consistent with other studies (Flores, Benvegnú, 2008; Loyola Filho et al., 2002; Loyola Filho et al., 2008). As found in others cities, analgesics were the most consumed drugs by those self-medicating, used mainly for headache and migraine, Despite being medications that can be dispensed without professional prescription, these drugs require special attention because they can cause nephropathy, hepatoxicity and possible drug-induced overuse (Vilarino et al., 1998; Loyola Filho et al., 2002; Naim, Escher, 2010). These differences in prevalences show local variations in relation to self-medication, making understanding this phenomenon especially relevant for the development of regional policies focused on promoting the rational use of medicines.

The inappropriate use of medicine extended to children of families in one fifth of those interviewed, being associated with the administration of drugs to their own children without professional prescription. The prevalence in this study was lower than that found in Limeira-Sao Paulo State and Piracicaba-São Paulo State (56\%), where administration of medicines to children was reported by half of respondents (Pereira et al., 2007). An interesting finding was the similarity between drug classes used by adults in self-medications and administrated without prescriptions among children. The influence of the family can lead to children becoming accustomed to consuming medicines on their own initiative, promoting self-medication in future generations (Pereira et al., 2007). In the present study, the strong association between individuals who practiced self-medication and those who administered medicine without prescription to their children ( $90 \%)$ seems to corroborate this notion.

Most interviewees claimed being aware of the risks associated with self-medication, demonstrating that lack of knowledge about medications was insufficient to abolish self-medication and that orientation of the population is insufficient to reduce inappropriate use of medicines, as discussed in other papers (Arrais et al., 1997; Flores, Benvegnú, 2008; Vitor et al., 2008). Importantly, only a small proportion of individuals were prevented from buying drugs without prescriptions, a fact that contributes to self-medication and corroborates results of other studies calling for greater control and restrictions on the dispensing of drugs in pharmaceutical establishments (Pereira et al., 2007).

In this study, efforts were made to avoid possible biases. The sample size calculation drew on data from the Census database, the sample was stratified, the selection 
of participants was random, the collection procedure was standardized and teams were trained. Nevertheless, this study was done in a city setting, and therefore definitive conclusions about inappropriate use of medicines in other locations must be drawn with caution. The features of the sample collected was similar to features of the population as a whole for the variables age, marital status, family income and schooling, but there was greater participation of women than men due to the timetabling of interviews. Prescriptions provided by the interviewees were used to evaluate the parameters related to prescription medication whereas to assess self-medication, patients were asked about the practice and drugs used, with no time limit for variables, a fact which may have led to overestimates compared with studies that specified a particular timeframe. Regarding the evaluation of drug interactions, our analysis was limited to the database provided by the portal drugs. com, but it is reasonable to assume that all common and important interactions were considered.

In conclusion, inappropriate use of medicines occurs across all strata of the population of Diamantina-Minas Gerais State. We urge educational activities to provide direct and objective information about the indiscriminate use of medicines, in order to highlight the risks posed by consumption of these products. However, these actions alone are insufficient without enforcing effective measures to curb the dispensing of prescription-only products and promoting the rational use of medication.

\section{REFERENCES}

ALMEIDA, O.P.; RATTO, L.; GARRIDO, R.; TAMAI, S. Fatores preditores e conseqüências clínicas do uso de múltiplas medicações entre idosos atendidos em um serviço ambulatorial de saúde mental. Rev. Bras. Psiquiatr., v.21, p.152-157, 1999.

AQUINO, D.S.D. Por que o uso racional de medicamentos deve ser uma prioridade? Ciênc. Saúde Coletiva, v.13, p.733-736, 2008.

ARRAIS, P.S.D.; COELHO, H.L.L.; BATISTA, M.D.C.D.S.; CARVALHO, M.L.; RIGHI, R.E.; ARNAU, J.M. Perfil da automedicação no Brasil. Rev. Saúde Pública, v.31, p.7177, 1997.

BRASIL. Instituto Brasileiro de Geografia e Estatística. IBGE. População e Domicílios - Censo 2000 com Divisão Territorial 2001. Available at: <http://www.ibge.gov.br/ cidadesat/topwindow.htm>Acessed on: 16 mar. 2011.
BRASIL. Ministério da Saúde. Secretaria de Ciência, Tecnologia e Insumos Estratégicos. Departamento de Assistência Farmacêutica e Insumos Estratégicos. Relação Nacional de Medicamentos Essenciais - Rename. 6ed. Brasília, Editora do Ministério da Saúde, 2008. Available at: <http://www. anvisa.gov.br/medicamentos/essencial.htm $>$. Acessed on: 16 mar. 2011.

BRASIL. Registros de Intoxicações. Sistema Nacional de Informação Tóxico-Farmacologica - SINITOX, 2009. Available at: < http://www.fiocruz.br/sinitox_novo/cgi/ cgilua.exe/sys/start.htm?sid=349>. Acessed on: 18 nov. 2011 .

CARVALHO, M.F.D.; PASCOM, A.R.P.; SOUZA JR, P.R.B.D.; DAMACENA, G.N.; SZWARCWALD, C.L. Utilization of medicines by the Brazilian population, 2003. Cad. Saúde Pública, v.21, p.S100-S108, 2005.

FICK, D.M.; COOPER, J.W.; WADE, W.E.; WALLER, J.L.; MACLEAN, J.R.; BEERS, M.H. Updating the Beers criteria for potentially inappropriate medication use in older adults: results of a US consensus panel of experts. Arch. Intern. Med., v.163, p.2716-2724, 2003.

FLORES, V.B.; BENVEGNÚ, L.A. Perfil de utilização de medicamentos em idosos da zona urbana de Santa Rosa, Rio Grande do Sul, Brasil. Cad. Saúde Pública, v.24, p.14391446, 2008.

FLORES, L.M.; MENGUE, S.S. Uso de medicamentos por idosos em região do sul do Brasil. Rev. Saúde Pública, v.39, p.924-929, 2005.

HANRATTY, C.G.; MCGLINCHEY, P.; JOHNSTON, G.D.; PASSMORE, A.P. Differential pharmacokinetics of digoxin in elderly patients. Drugs Aging, v.17, p.353-362, 2000.

HOHL, C.M.; DANKOFF, J.; COLACONE, A.; AFILALO, M. Polypharmacy, adverse drug-related events, and potential adverse drug interactions in elderly patients presenting to an emergency department. Ann. Emerg. Med., v.38, p.666$671,2001$.

JAMES, J.S.; GINA, C.; JEFFREY, D.A.; LOWE, R.S.; ANWARUL, K.; MARK, L. Part II: Cardiac drug and psychotropic drug interactions: significance and recommendations. Gen. Hosp. Psychiatry, v.21, p.408-429, 1999. 
LOYOLA FILHO, A.I.D.; UCHOA, E.; FIRMO, J.O.A.; LIMACOSTA, M.F. Influência da renda na associação entre disfunção cognitiva e polifarmácia: Projeto Bambuí. Rev. Saúde Pública, v.42, p.89-99, 2008.

LOYOLA FILHO, A.I.D.; UCHOA, E.; GUERRA, H.L.; FIRMO, J.O.A.; LIMA-COSTA, M.F. Prevalência e fatores associados à automedicação: resultados do projeto Bambuí. Rev. Saúde Pública, v.36, p.55-62, 2002.

NAIM, R.O.; ESCHER, M. Self medication with analgesics: what are the risks?. Rev. Med. Suisse, v.6, p.1338-1341, 2010 .

PANIZ, V.M.V.; FASSA, A.G.; FACCHINI, L.A.; BERTOLDI, A.D.; PICCINI, R.X.; TOMASI, E.; THUMÉ, E.; SILVEIRA, D.S.D.; SIQUEIRA, F.V.; RODRIGUES, M.A. Acesso a medicamentos de uso contínuo em adultos e idosos nas regiões Sul e Nordeste do Brasil. Cad. Saúde Pública, v.24, p.267-280, 2008.

PEREIRA, F.S.V.T.; BUCARETCHI, F.; STEPHAN, C.; CORDEIRO, R. Automedicação em crianças e adolescentes: J. Pediatr., v.83, p.453-458, 2007.

RIBEIRO,A.Q.; ROZENFELD, S.; KLEIN, C.H.; CÉSAR, C.C.; ACURCIO, F.D.A. Inquérito sobre uso de medicamentos por idosos aposentados, Belo Horizonte,MG. Rev. Saúde Pública, v.42, p.724-732, 2008.

ROYSTON, J.P. Algorithm AS 181: the W test for normality. Appl. Stat., v.31, p.176-180, 1982.
ROZENFELD, S.; FONSECA, M.J.M.; ACURCIO, F.A. Drug utilization and polypharmacy among the elderly: a survey in Rio de Janeiro City, Brazil. Rev. Panam. Salud Publica, v.23, p.34-43, 2008.

SÁ, M.B.E.; BARROS, J.A.C.D.; SÁ, M.P.B.D.O. Automedicação em idosos na cidade de Salgueiro-PE. Rev. Bras. Epidemiol., v.10, p.75-85, 2007.

SECOLI, S.R. Polifarmácia: interações e reações adversas no uso de medicamentos por idosos. Rev. Bras. Enferm., v.63, p.136-140, 2010.

VILARINO, J.F.; SOARES, I.C.; SILVEIRA, C.M.D.; RÖDEL, A.P.P.; BORTOLI, R.; LEMOS, R.R. Perfil da automedicação em município do Sul do Brasil. Rev. Saúde Pública, v.32, p.43-49, 1998.

VITOR, R.S.; LOPES, C.P.; MENEZES, H.S.; KERKHOFF, C.E. Padrão de consumo de medicamentos sem prescrição médica na cidade de Porto Alegre, RS. Ciênc. Saúde Coletiva, v.13, p.737-743, 2008.

WORLD HEALTH ORGANIZATION. Collaborating Centre for Drug Statistics Methodology. Guidelines for ATC classification and DDD assignment 2010. Oslo, 2009. Available at: < http://www.whocc.no/news/340.html>. Acessed on: 16 Mar. 2011.

Received for publication on $21^{\text {st }}$ Mach 2011 Accepted for publication on $23^{\text {rd }}$ November 2011 